\title{
KONSEP PENGELOLAAN KEKAYAAN DALAM ISLAM
}

\author{
Choirunnisak \\ Sekolah Tinggi Ekonomi dan Bisnis Syariah (STEBIS) Indo Global Mandiri \\ Email: choirunnisak-umar@stebisigm.ac.id
}

\begin{abstract}
Abstrak
Penelitian ini bertujuan untuk mengetahui pengelolaan kekayaan dalam Islam. Ada empat konsep pengelolaan kekayaan dalam Islam, tentunya semua ini harus berdasarkan syariah: 1). (bisnis), tabungan di bank, investasi pada properti, dan lain-lain. 2). Peningkatan atau Perbaikan Kekayaan. Meningkatkan jumlah pengembalian dari capital gain dan pendapatan termasuk melalui penggunaan leverage (utang). 3.) Perlindungan Kekayaan. Melindungi kekayaan melalui manajemen risiko dan asuransi.4) Distribusi Kekayaan. Mendistrbusikan kekayaan melalui zakat dan faraid (warisan).
\end{abstract}

Kata Kunci: Pengelolaan, Kekayaan, Islam

\section{Dasar Pemikiran}

Pengelolaan kekayaan Islami yang dikenal juga sebagai perencanaan keuangan keluarga secara syariah (Islamic Financial Planning)merupakan industri keuangan yang berfungsi untuk mengelola kekayaan masyarakat muslim untuk dapat diinvestasikan maupun dikelola dengan cara-cara yang halal dan thoyib. Industri keuangan pengelolaan kekayaan pribadi ini bermunculan karena semakin meningkatnya populasi keluarga muslim khususnya yang berpenghasilan tinggi. Industri pengelolaan harta dalam Islam atau Islamic Wealth Management (IWM) industri merupakan sektor keuangan yang mengelola harta kekayaan muslim kaya keuangan Islam yang paling cepat tumbuh dan berkembang. Sektor ini mewakili sekitar 1.3 triliun US\$ kekayaan peribadi muslim dari berbagai negara yang tergabung dalam Gulf Cooperation Council (GCC) saja.Kekayaan dalam jumlah yang signifikan berasal dari India, Malaysia, dan Indonesia.

Pertumbuhan sektor keuangan industri pengelolaan kekayaan secara Islami ini dipengaruhi oleh meningkatnya kekayaan pribadi masyarakat di kawasan negara Timur Tengah dan Asia Tenggara seperti harga sumber alam minyak yang terus meningkat secara drastis, diiringi dengan menguatnya dan meningkatnya permintaan terhadap 
produk yang memenuhi kriteria syariah kompliant oleh muslim yang berusaha untuk mengidentifikasi dengan ajaran Islam. Selain sumber daya alam minyak, yangterkait denganpenciptaan kekayaanbelum pernah terjadi sebelumnya. Kekayaan telah dikalikan dalam komunitas muslim karena pertumbuhan makro ekonomi yang luas dan kuat di negara-negara berkembangdi Asia, diversifikasi bisnis dan investasi keuangan di Timur tengah, dan investasi asing langsung baru di AsiaTenggara yang didorong oleh kenaikan komoditas harga (Shanmugam dan Zahari, 2009: 75).

Ruang lingkup IWM (industri pengelolaan kekayaan) bagi masyarakat muslim, secara umum sama seperti lembaga pengelolaan harta kekayaan secara konvensional atau perbankan swasta. Perbedaannya adalah industri ini tidak sekedar lembaga pengelolaan terhadap investasi. Ruang lingkup industri ini meliputi kewajiban dan manajemen risiko, meliputi juga pengelolaan harta warisan, danperencanaanpajak untuk individu dengan penghasilan yang tinggi (high net worth/ HNW). Secara praktis, perbedaan yang terletak pada penerapan prinsip-prinsip Islam di dalam seleksi investasi danmematuhipembatasanagamapada transfer kekayaan, perbankan swasta Islam pada dasarnya juga mempunyai tujuan yang sama dengan praktik perbankan swasta konvensional.

Indonesia, produk pengelolaan kekayaan peribadi telah menjadi salah satu produk yang ditawarkan di institusi keuangan syariah. Pengelolaan kekayaan peribadi (IWM) di Indonesia juga semakin berkembang seiring bertambahnya populasi keluarga muslim yang mempunyai penghasilan tinggi. Hadirnya industri pengelolaan kekayaan peribadi di Indonesia memudahkan keluarga muslim untuk dapat disiplin dalam menginvestasikan kekayaan mereka sesuai dengan prinsip-prinsip syariah. Beragam portofolio pengelolaan kekayaan seperti reksadana syariah, deposito, dan pasar modal syariah menjadi pilihan keluarga muslim menengah ke atas, untuk mengelola kekayaan mereka (Pengelolaan Kekayaan Peribadi. Diakses dari situs pada tanggal 22 Desember 2015. http://www.syariahmandiri.co.id/category/edukasi-syariah/islamic-knowledge/).

Selanjutnya dalam pembahasan jurnal ini fokus terhadap definisi kekayaan dalam Islam, penciptaan kekayaan dalam Islam, dan siklus pengelolaan kekayaan tersebut, hukum waris Islam, ukuran dan prospek sektor industri pengelolaan kekayaan muslim, dan tantangan untuk kekayaan Islam sebagai kelanjutan pertumbuhan kekayaan global 
Islam dan pengelolaan kekayaan Islami. Berangkat dari sini penulis tertarik membahas bagaimana konsep kekayaan dalam Islam.

\section{Pembahasan}

\section{Konsep Kekayaan dalam Perspektif Islam}

Islam sebagai agama yang syumul yang mengatur segala ruang lingkup kehidupan manusia termasuk di dalamnya menyangkut masalah harta. Harta kekayaan dalam Islam merupakan milik Allah secara mutlak. Ayat al-Quran berulang kali menjelaskan mengenai hak mutlak Allah terhadap harta kekayaan yang ada di bumi ini.Manusia hanya sebagai wakil yang dipercayakan untuk menggunakan dan mengelola harta kekayaan tersebut dengan cara-cara yang diperbolehkan. Allah sebagai pemilik segala bumi beserta isinya, Jadi kepemilikan manusia hanyalah bersifat relatif, sebatas hanya untuk mengelola dan memanfaatkan sesuai dengan ketentuan-ketentuan yang ditetapkan syariat (Mardani, 2012: 61-62). Penjelasan mengenai hal tersebut disebutkan dalam alQuran kurang lebih sebanyak 20 kali. Diantaranya terdapat dalam QS. Al- A'raf; 128, QS. Al-Hadid; 5, dan QS. Al-Baqarah; 29-30 (Vogel dan Hayes, 2007: 76).

Kekayaan termasuk jenis harta yang menjadi kecenderungan manusia terhadapanya. Oleh karena itu, sepatutnya manusia menyadari bagaimana sebenarnya kedudukan atau status harta yang dikaruniakan oleh Allah. Kedudukan atau status harta berdasarkan al-Quran adalah sebagai berikut:

a. Harta sebagai titipan, karena manusia tidak mampu mengadakan benda dari tiada menjadi ada. Oleh karena itu, wajib bagi manusia untuk menginfakkan harta yang diperolehnya.

b. Harta sebagai perhiasan hidup yang memungkinkan manusia dapat menikmatinya dengan baik dan tidak berlebih-lebihan. (QS. Ali- Imran; 14).

c. Harta sebagai ujian keimanan. Hal ini terutama menyangkut soal cara mendapatkan dan memanfaatkannya, apakah sesuai dengan Islam atau tidak. (QS. Al- Anfal; 28).

d. Harta sebagai bekal atau sarana beribadah. Menurut pandangan Islam, harta bukanlah tujuan, namun hanya sebagai sarana untuk memperoleh ridha Allah SWT. yakni untuk melaksanakan kegiatan zakat, infak, dan sedekah. Hal ini dicatumkan di dalam al-Quran surat at- Taubah; 14 dan QS. 134 (Aravik, 2016: 6-8). 
Konsekuensi logis ayat-ayat al-Quran di atas adalah sebagai berikut:

a) Manusia bukan pemilik mutlak, tetapi dibatasi oleh hak-hak Allah sehingga wajib baginya untuk mengeluarkan sebagian kecil hartanya untuk berzakat dan ibadah lainnya

b) Cara-cara pengambilan manfaat harta mengarah kepada kemakmuran bersama, pelaksanaannya dapat diatur oleh masyarakat melalui wakil-wakilnya.

c) Harta perorangan boleh digunakan untuk umum, dengan syarat pemiliknya memperoleh imbalan yang wajar.

Islam mengharuskan muslim untuk memperoleh harta secara berkelanjutan dan menginfakkan harta kekayaan tersebut. Maksudnya, ajaran Islam menganjurkan dan mengharuskan umatnya untuk berusaha dan bekerja keras untuk dapat memperoleh keuntungan yang halal bagi dirinya sendiri dan juga bagi keluarganya. Tidak hanya itu, Islam juga mengharuskan umatnya untuk bekerja keras dan berupaya untuk mencapai kesempurnaan dan kelayakan profesi atau pekerjaan bagi dirinya. Jadi, pengelolaan harta kekayaan dalam Islam meliputi penciptaan/ pengelolaan harta, peningkatan jumlah harta kekayaan, perlindungan terhadap harta kekayaan, pendistribusian harta kekayaan, dan pemurnian harta kekayaan.

\section{Aplikasi Pengelolaan Kekayaan dalam Islam}

Pengelolaan kekayaan secara Islami meliputi aspek perolehan atau penciptaan harta, peningkatan harta kekayaan, perlindungan harta, pendistribusian kekayaan, dan pemurnian kekayaan. Syariat Islam mengajarkan bahwa harta kekayaan dapat digunakan untuk banyak tujuan namun tidak diperbolehkan untuk dibelanjakan pada hal-hal yang dilarang secara syara'. Menurut syariat Islam, kebutuhan untuk memperoleh harta kekayaan merupakan sebuah motivasi untuk bekerja keras dan berusaha. Jadi, dengan demikian, kemampuan seorang muslim dalam meperoleh harta kekayaan dan mendistribusikan harta kekayaan tersebut akan memberikan harapan kepada pihak yang membutuhkan harta.

Kebutuhan akan pengelolaan harta kekayaan akan menciptakan sikap disiplin dalam menjaga harta kekayaan yang dapat mendukung kesejateraan sebuah keluarga maupun masyarakat. Penghematan terhadap pendapatan atau keuntungan yang 
diperoleh oleh umat muslim walaupun dalam porsi kecil, maka hal ini akan membantu masyarakat muslim khususnya untuk melawan atau mengatasi masalah sifat konsumtif dan inflasi. Gambar berikut ini merupakan siklus pengelolaan kekayaan yang meliputi perolehan harta kekayaan, peningkatan jumlah kekayaan, perlindungan kekayaan, dan pendistribusian kekayaan, yang secara umum berlaku baik di Bank Islam maupun bank konvesional.

Distribusi Harta

(Melepaskankekayaan melalui warisan

dankepercayaan)
Perolehan atau penciptaan harta

(perolehan harta melaluibisnis,

penyimpanan dibank, daninvestasi

Perlindungan terhadap harta

Memertahankan modal melaluimanajemen risiko, asuransi, dankepercayaan

Peningkatan Jumlah Kekayaan Meningkatkan total return (pengembalian) dari capital gains dan pendapatan, termasuk melahi penganuh penggunaan leverage (utang).

Siklus di atas meliputi

1) Penciptaan Kekayaan. Menciptakan kekayaan dilakukan melalui usaha

2) (bisnis), tabungan di bank, investasi pada properti, dan lain-lain.

3) Peningkatan atau Perbaikan Kekayaan. Meningkatkan jumlah pengembalian dari capital gain dan pendapatan termasuk melalui penggunaan leverage (utang).

4) Perlindungan Kekayaan. Melindungi kekayaan melalui manajemen risiko dan asuransi.

5) Distribusi Kekayaan. Mendistrbusikan kekayaan melalui zakat dan faraid (warisan). 


\section{Perolehan atau Penciptaan Kekayaan}

Perolehan harta dilakukan dengan cara usaha (amal) atau mata pencaharian (maliyah) yang halal dan sesuai dengan aturan Allah SWT. Ayat al-Quran dan hadits Nabi banyak yang mendorong atau menganjurkan manusia untuk berusaha. Salah satunya terdapat dalam QS. Al- Mulk; 15 dan QS. Al- Baqarah; 267.Usaha ini merupakan usaha yang paling baik, yaitu memperoleh harta dengan tangan dan tenaga sendiri. Hal ini seperti yang disabdakan oleh Rasulullah SAW. yang diriwayatkan oleh Rufaah bin Rafi'; Bahwa Nabi SAW pernah ditanya tentang usaha apa yang paling baik. Nabi SAW menjawab: "Setiap usaha seseorang dengan tangannya (tenaganya) sendiri, dan setiap jual beli yang baik”.

Cara memperoleh harta yaitu dengan cara yang diperbolehkan, manusia dianjurkan untuk berusaha terlebih dahulu, sebagaimana yang ditegaskan Allah dalam QS. AlJumu'ah; 10. Baru setelah berusaha, manusia dianjurkan untuk berdoa agar diberi rezeki atau limpahan karunia Allah SWT dalam bentuk rezeki, hal ini sebagaimana yang dijelaskan oleh Allah dalam QS. An- Nisa; 32. Jadi, dengan demikian, maka Allah akan memperkenankan rezeki bagi siapa yang dikehendakinya, hal ini ditegaskan dalam QS. Al- Jumu'ah; 4.Islam tidak membatasi cara perolehan harta, selama itu dilakukan dalam prinsip umum yaitu halal dan baik. Islam tidak melarang mencari harta sebanyak mungkin, karena hak Allah untuk menetapkan rezeki.

Manusia dapat mengusahakan perolehan kekayaan, namun tetap meyakini dan mempercayai bahwa semua kekayaan dan harta adalah mutlak milik Allah dan manusia hanya dipercayai sebagai wakil yang dipercayakan untuk menggunakan dan mengelola harta tersebut dengan sebaik-baiknya. Jika dikaitkan dengan halnya harta, maka bentuk usaha atau cara memperoleh kekayaan atau harta dalam perspektif Islam ada dua bentuk, yaitu:

a. Memperoleh kekayaan secara langsung sebelum dimiliki oleh orang lain. Contoh, menggarap tanah yang mati yang belum dimiliki (ihya al-mawat). Nabi SAW bersabda:

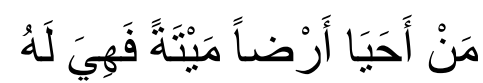


"Barang siapa yang menghidupkan tanah yang mati, maka ia berhak memilikinya".

b. Memperoleh harta yang telah dimiliki oleh orang lain atau seseorang melalui transaksi. Hal ini dapat diakukan melalui dua cara, yaitu (Ghazali, Hasan dan Shiddiq, 2012: 24-26):

1) Perolehan harta yang terjadi secara langsung dengan sendirinya atau yang disebut dengan ijabary, dan siapapun tidak mampu menolaknya. Contohnya adalah harta yang diperoleh melalui warisan.

2) Perolehan harta langsung namun terjadi dengan tidak sendirinya, dengan kehendak sendiri, yang disebut dengan ikhtiyari. Contohnya adalah kehendak sepihak (hibah), atau melalui pemberian maupun perjanjian timbal balik antara dua atau beberapa pihak. Dua bentuk perolehan harta ini harus dilakukan dengan halal lagi baik. Contohnya adalah jual beli.

Berdasarkan pejelasan diatas, Islam berpendapat dan mengajarkan bahwa harta atau kekayaan dapat diperoleh oleh seseorang dengan melalui usaha dan juga melalui pewarisan (harta warisan). Islam melarang perbuatan yang menyia-menyiakan harta kekayaan. Uang di dalam Islam dapat diusahakan untuk memperoleh keuntungan darinya, seperti dengan jalan diinvestasikan, serta dapat dibelanjakan melalui jalan atau cara-cara yang halal dan sesuai dengan prinsip-prinsip kebolehan di dalam Islam.

Mematuhi ajaran-ajaran Islam yang demikian itu, muslim dapat memantaskan dirinya, keluarganya dan juga masyarakat (ummah) dapat memperoleh kebahagiaan dan imbalan-imbalan baik di dunia ini maupun di akhirat kelak.Harta kekayaan harus diusahakan untuk menghasilkan keutungan dan didistribusikan atau dibagikan sebagamana cara-cara yang diperbolehkan menurut syariat Islam. Maksudnya adalah pendapatan atau modal dalam Islam tidak boleh dihasilkan atau diperoleh dari cara-cara yang aktivitas usaha atau bisnis yang dilarang.

Islam tidak melarang akuisisi atau memperoleh harta kekayaan oleh peribadi manusia atau pemilik kekayaan. Namun, cara-cara yang dilakukan sebagai upaya mengembangkan harta kekyaaan yang terlalu obsesif atau berlebihan maka akan mengarah dapat mengesampingkan bagian yang paling penting dari sisi spiritualitas manusa itu sendiri. Hal yang sama juga berlaku terhadap pemerintah dan 


\section{4 | Choirunnisak Konsep Pengelolaan Kekayaan dalam Islam}

jugamasyarakat. Islamtidak menganggap akumulasi kekayaannegatif, meskipun demikian, Islam tidak membenarkan akumulasi kekayaanyang berlebihan hanya pada segolongan kalangan individu atau masyarakat saja. Sistem zakat sebagai salah satu pilar atau hukum Islam merupakan pendistribusian yang efektif terhadap harta kekayaan dari para pemilik kekayaan (orang yang mampu) kepada orang atau pihak yang tidak memiliki harta kekayaan. Pembagian harta berdasarkan jalan warisan juga merupakan salah satu sarana untuk membagi harta diantara sesama umat Islam.

Harta tidak diperbolehkan diperoleh dengan cara-cara yang melanggar aturan syariat. Bentuk-bentuk larangan yang berkaitan dengan perolehan kekayaan adalah:

a) Cara memperoleh harta, dilarang untuk bekerja atau berusaha yang dapat melupakan kematian (QS. At- Takastur; 1-2), melupakan dzikrullah, melupakan shalat dan zakat (QS. An-Nur; 37), serta memusatkan kekayaan yang hanya pada sekolompok golongan tertentu (al-Hasyr; 7).

b) Perkara-perkara yang merendahkan martabat manusia, seperti: memakan harta sesama manusia dengan cara yang batil (firman Allah SWT dalam QS. Al- baqarah; 188).

c) Dilarang menempuh usaha yang haram, seperti melalui kegiatan riba, judi, jual beli barang haram, mencuri, merampok, penggabasan (QS. Al-Maidah; 38), berlaku curang dalam takaran dan timbangan (QS. Al- Muthaffin; 1-6).

d) Memakan harta dengan cara penipuan (firman Allah SWT dalam QS. Al- an'am; 152).

e) Memperoleh kekayaan dengan cara melanggar janji dan sumpah (firman Allah SWT dalam QS. an- Nahl; 92).

f) Perkara-perkara yang merugikan hak perorangan dan kepentingan sebagian atau keseluruhan masyarakat, berupa perdagangan yang memakai bunga (QS. ali- Imran; $34)$.

g) Penimbunan harta (QS. Al- Anfal ; 34).

h) Pemborosan (aktivitas yang merupakan pemborosan/ mubazir). (QS. al- Isra'; 26) baik yang menghabiskan harta peribadi masyarakat. 
3) Memproduksi, memperdagangkan, dan mengonsumsi barang-barang terlarang seperti narkotika, dan minuman keras, kecuali yang diperuntukkan untuk ilmu pengetahuan dan kesehatan (Suhendi, 2013: 15-18).

\section{Peningkatan Jumlah Harta Kekayaan Menurut Perspektif Islam}

Harta kekayaan dalam Islam maksudnya adalah mengusahakan harta atau memperoleh kekayaan tersebut hanya melalui atkivitas investasi yang diperbolehkan secara syariat atau produk keuangan yang memenuhi kriteria syariat. Lebih khususnya lagi produk keuangan tersebut haruslah terbebas dari unsur-unsur yang dilarang yaitu bebas riba, dan bebas dari unsur ketidakpastian (gharar), dan judi (maisir). Terlebih, perolehan harta harus terbebas atau tidak boleh mengandung sesuatu yang diharamkan seperti babi dan alkohol. Produk-produk keuangan yang sesuai dengan kriteria syariah meliputi saham, reksadana syariah, obligasi syariah (sukuk), asuransi syariah (takaful), investasi berdasarkan akad wadi'ah dan mudharabah, maupun investasi pada produk keuangan baru yang diatur atau disusun sesuai berdasarkan kriteria syariah (syariah kompliant).

\section{Perlindungan Kekayaan}

Perlindungan kekayaan sangat penting menurut Islam. Oleh karena tu, manajemen risiko dan asuransi Islam (takaful) memainkan peran penting dalam praktek Islamic Wealth Management. Produk keuangan investasi syariah harus terstruktur untuk menghindari gharar, sesuai dengan ajaran Islam yakni sebagai upaya melindungi kekayaan.

\section{Pemurnian dan Distribusi Kekayaan}

Islam mewajibkan kebersihan baik fisik (badan) dan rohani. Kebersihan rohani melibatkan kebersihan pikiran, sehingga bebas dari niatan buruk atau keinginan untuk melakukan tindakan yang melanggar hukum dan kebersihan hati sehingga terbebas dari iri hati, kemunafikan serta keinginan jahat. Kebersihan spiritual terkait dengan harapan, kebenaran, pengampunan, dan kasih sayang. Pembebanan zakat dalam Islam bertujuan 


\section{6 | Choirunnisak Konsep Pengelolaan Kekayaan dalam Islam}

membantu Muslim dalam mencapai kebersihan spiritual dan pemurnian kekayaan. Zakat adalah wajib bagi setiap muslim yang kekayaanya telah mencapai tingkat tertentu untuk membayar zakat. Besarnya zakat yakni 2.5\% dari aset keuangan yang dimiliki atau barang yang dapat diperdagangkan. Pengadaan zakat merupakan sarana mempersempit kesenjangan antara kaya dan miskin dengan membantu memenuhi kebutuhan masyarakat yang masih kurang beruntung.Distribusi kekayaan juga terjadi melalui hukum waris atau dalam Islam dikenal dengan istilah faraid. Tujuan dari faraid yakni mengatur distribusi harta seorang Muslim setelah kematian.

\section{a. Faraid}

Faraid atau hukum waris Islam, menetapkan secara otomatis pasangan, orang tua kandung, anak-anak dikenal sebagai ahli waris sesuai yang tertuang dalam Al-Qur'an. Cucu, anak angkat, anak haram, orang tua asuh, orang tua non-Muslim, anak-anak nonMuslim, dan anggota keluarga non-Muslim tidak dimasukkan sebagai ahli waris menurut hukum Islam. Seorang Muslim dapat memberikan sepertiga (1/3) dari harta kekayaannya saat dia akan meninggal. Oleh karena itu, sepertiga dari harta kekayaannya dapat diwariskan pada ahli waris diluar syariah melalui ketentuan surat wasiat. Sebuah wasiat (wasiyat) dianggap kewajiban agama dari semua Muslim baik hanya berupa pesan lisan maupun tertulis. Biasanya, kemauan atau wasiat harus dinyatakan di hadapan dua saksi agar valid atau sah sehingga dapat diterima jika ditulis dalam tulisan tangan yang dikenal dari pewaris dan ditanda tangani sepengetahuannya.

Tabel 6.1. Perbedaan antara Hukum Islam dan non-Islam

\begin{tabular}{|l|l|}
\hline \multicolumn{1}{|c|}{ Islam } & \multicolumn{1}{|c|}{ Non-Islam } \\
\hline $\begin{array}{l}\text { Hukum Islam menentukan disposisi } \\
\text { dari mayoritas aset mendiang. }\end{array}$ & $\begin{array}{l}\text { Disposisi dari semua aset mendiang } \\
\text { ditentukan oleh orang yang meninggal } \\
\text { (pewaris). }\end{array}$ \\
\hline $\begin{array}{l}\text { Distribusi kekayaan seseorang yang } \\
\text { meninggal untuk ahli waris sesuai al- } \\
\text { Qur'an dan djadikan dasar hukum waris } \\
\text { (pasangan, anak, dan orang tua }\end{array}$ & $\begin{array}{l}\text { menentukan distribusi kekayaannya } \\
\text { kandung pasangan, anak, orang tua } \\
\text { kandung, dan ahli waris lainnya yang }\end{array}$ \\
\hline
\end{tabular}




\begin{tabular}{|l|l|}
\hline $\begin{array}{l}\text { dibuat untuk pendstribusian yang telah } \\
\text { ditentukan tanpa seijin pewaris. }\end{array}$ & \\
\hline $\begin{array}{l}\text { Hanya sepertiga (1/3) dari harta } \\
\text { kekayaan dapat didistribusikan kepada }\end{array}$ & Pewaris mungkin menentukan disposisi \\
ahli waris di luar ketentuan al-Qur'an \\
$\begin{array}{l}\text { tanpa persetujuan dari ahli waris yang } \\
\text { ditentukan al-Qur'an. }\end{array}$
\end{tabular}

\section{b. Zakat}

Membayar zakat adalah sebagai bentuk ibadah kepada Allah. Makna asli dari kata zakat adalah "pensucian" dan "pertumbuhan". Menurut istilah zakat berarti kewajiban seorang muslim untuk mengeluarkan nilai bersih dari kekayaannya yang tidak melebihi satu nisab, diberikan kepada mustahik dengan beberapa syarat yang telah ditentukan (alJaziri, 1990: 590). Zakat, dalam pengertian suci adalah membersihkan diri, jiwa, dan harta. Seseorang yang mengeluarkan zakat berarti dia telah membersihkan diri dan jiwanya dari penyakit kikir, membersihkan hartanya dari hak orang lain. Sementara zakat dalam pengertian berkah adalah sisa harta yang sudah dikeluarkan zakatnya secara kualitatif akan mendapat berkah dan akan berkembang walaupun secara kuantitatif jumlahnya berkurang.

Membayar zakat merupakan kewajiban bagi setiap umat Islam. Membayar zakat adalah merupakan rukun Islam yang ketiga, dan ini juga pentingtidak berbeda dari kewajiban-kewajiban lainnya. Membayar zakat berarti "memberikan persentase tertentu dari aset tertentu untuk diberikan kepada orang yang ada dalam klasifikasi tertentu. "Seorang Muslim percaya bahwa dengan membayar zakat akan membersihkan hati dari sifat-sifat buruk (Shanmugam dan Zahiri, 2009: 78-79). Zakat secara umum dibagi menjadi dua macam yaitu: pertama, zakat yang berhubungan dengan jiwa manusia (badan) yaitu zakat fitrah, dan kedua, zakat yang berhubungan dengan harta atau zakat mal (Soemitra, 2009: 413-419).

1) Zakat Fitrah/Fidyah 
Zakat fitrah adalah sejumlah bahan makanan pokok yang dikeluarkan pada bulan Ramadhan oleh setiap Muslim bagi dirinya dan bagi orang yang ditanggungnya yang memiliki kelebihan makanan pokok untuk sehari pada hari Raya Idul Fitri.

2) Zakat Harta (Mal)

Zakat harta adalah bagian harta yang disisihkan oleh seorang Muslim atau badan yang dimiliki oleh orang Muslim sesuai dengan ketentuan agama untuk diberikan kepada yang berhak menerimanya.

Secara umum harta-harta yang wajib dizakatkan adalah:

a) Emas, Perak dan Uang

Seorang Muslim yang mempunyai emas dan perak wajib mengeluarkan zakat bila sesuai dengan nisab dan haul. Adapun nisab emas adalah 20 dinar setara dengan 85 gr dan nisab perak adalah 200 dirham atau setara dengan 672 gr.

b) Harta Perniagaan

Harta perniagaan adalah semua yang diperuntukkan untuk diperjualbelikan dalam berbagai jenisnya, baik berupa barang seperti alat-alat, pakaian, makanan, perhiasan, dan lain-lain. Perniagaan tersebut diusahakan secara perorangan atau perserikatan seperti: CV, PT, Koperasi, dan sebagainya. Nisab zakat perdagangan sama dengan nisab emas yaitu senilai 85 gr emas, dengan kadarnya zakat sebesar 2,5\%. Zakat dapat dibayar dengan uang atau barang dan dikenakan pada perdagangan maupun perseroan.

c) Hasil Pertanian

Hasil pertanian adalah hasil tumbuh-tumbuhan atau tanaman yang bernilai ekonomis seperti biji-bijian, umbi-umbian, sayur-mayur, buah-buahan, tanaman hias, rumput-rumputan, dedaunan, dan lain-lain. Nisab hasil pertanian adalah 5 wasq atau setara dengan $750 \mathrm{~kg}$. Kadar zakat untuk hasil pertanian apabila diairi dengan air hujan, atau sungai/mata/air, maka 10\%, apabila diairi dengan cara disiram/irigasi (ada biaya tambahan) maka zakatnya 5\%.

d) Binatang Ternak

Binatang ternak yang wajib dizakatkan adalah unta, sapi dan kerbau, kambing dan biri-biri dengan syarat sampai senisab, telah mencapai haul, digembalakan, dan tidak dipekerjakan. Untuk hewan ternak yang akan dikeluarkan zakatnya, maka hewan itu harus 1) sehat dalam arti tidak luka, cacat, pincang, dan kekurangan lain yang 
mengurangi manfaat dan harganya. 2) Betina dan cukup umur berdasarkan ketentuan nash. Nisab dan kadar zakat hewan berbeda untuk setiap jenis hewannya.

e) Rikaz (Harta Terpendam)

Rikaz adalah harta yang terpendam sejak zaman purbakala dan ditemukan pada sebidang tanah yang tidak dimiliki oleh seseorang seperti emas, perak, besi, timah, bejana, dan lain sebagainya. Terhadap barang terpendam ini wajib dikeluarkan zakatnya $1 / 5$.

f) Barang Tambang

Ma'din (hasil tambang) adalah benda-benda yang terdapat di dalam perut bumi dan memiliki nilai ekonomis seperti emas, perak, timah, tembaga, marmer, giok, minyak bumi, batu bara, dan lain-lain. Kekayaan laut adalah segala sesuatu yang dieksploitasi dari laut seperti mutiara, ambar, marjan, dan lain-lain. Menurut mazhab Hanafi dan qaul mazhab Syafi'i berpendapat bahwa yang wajib dikeluarkan zakatnya adalah 1/5. Sedangkan mazhab Maliki, Syafi'i, dan Hambali berpendapat bahwa yang wajib dikeluarkan zakatnya adalah 1/40.

\section{g) Zakat Profesi}

Zakat profesi adalah zakat yang dikeluarkan dari penghasilan profesi (hasil profesi) bila telah mencapai nisab. Profesi dimaksud mencakup profesi pegawai negeri atau swasta, konsultan, dokter, notaris, akuntan, artis, wiraswasta, dan lain-lain. Pendapat ulama yang berkembang saat ini, menganalogikan zakat profesi kepada zakat pertanian, yakni dibayar ketika mendapatkan hasilnya, tanpa menunggu setahun. Demikian juga mengenai nisabnya, sebesar $1,350 \mathrm{~kg}$ gabah atau $750 \mathrm{~kg}$ beras. Zakat ini dibayarkan dari pendapatan bersih, bukan pendapatan kotor. Sedangkan tarifnya, menurut ulama kontemporer, dianalogikan kepada zakat emas dan perak yakni sebesar 2,5\%, atas dasar qiyas asy-syabah, yaitu dari segi waktu mengeluarkan dan nisabnya dianalogikan kepada zakat pertanian. Sedangkan dari segi tarifnya dianalogikan kepada zakat emas perak.

Harta merupakan titipan Allah SWT yang pada hakekatnya hanya dititipkan kepada kita sebagai manusia ciptaan-Nya. Terdapat kewajiban yang dibebankan pada pemiliknya untuk mengeluarkan zakat untuk kesejahteraan masyarakat, dan ada ibadah maliyah sunnah yakni sedekah dan infaq.Zakat merupakan ibadah yang mempunyai 
dimensi dan fungsi sosial ekonomi atau pemerataan karunia Allah dan juga merupakan solidaritas sosial, pernyataan rasa kemanusiaan dan keadilan, pembuktian persaudaraan Islam, pengikat persatuan umat dan bangsa, sebagai pengikat batin antara golongan kaya dengan miskin dan sebagai penghilang jurang yang menjadi pemisah antara golongan yang kuat dengan yang lemah (Soemitra, 2009: 413-419).

\section{Prospek untuk Pengelolaan Kekayaan secara Islami}

Dewasa ini, permintaan akan produk Islamic Wealth Management meningkat pesat. Hal ini terbukti dari semakin bertumbuhnya Islamic Private Equity Fund (PEF) di dunia. Laporan "Tapping Global High Net Worth Individuals" (Penelitian KFH 2008) menyatakan bahwa semakin banyak Muslim yang berpenghasilan tinggi yang beralih ke pengelolaan kekayaan secara Islami. Banyak dari kalangan Muslim yang berkomitmen kuat untuk menggunakan jasa keuangan yang sesuai dengan prinsip syariah dan menghindari investasi pada industri yang dipandang tidak sesuai dengan syariah, seperti

alkohol atau judi. Peningkatan transparansi keuangan dan pengungkapan dan pemantauan rutin terhadap kepatuhan oleh dewan syariah juga telah mendorong permintaan terhadap investasi yang sesuai dengan syariah. Secara umum, penerimaan terhadap jasa keuangan syariah dan produk, seperti sukuk, ekuitas swasta, dan produk terstruktur, telah berkembang (Shangmugam dan Zahiri, 2009: 7980).

Tahun 2008, kekayaan pribadi kalangan Muslim diperkirakan telah mewakili sekitar 5 persen (US\$ 2,1 triliun) dari kekayaan pribadi global, naik dari perkiraan 4,8 persen (US\$ 1,9 trilyun) pada tahun 2007. Kekayaan pribadi Muslim diproyeksikan naik pada tahun 2020 ke US\$ 4 triliun sebagaimana peningkatan populasi Muslim dunia diperkirakan 2,5 miliar, naik dari perkiraan saat ini 1,5 miliar (Penelitian KFH 2008). Meskipun pertumbuhan sektor pengelolaan kekayaan Islam telah kuat, IWM menghadapi tantangan yang sama dengan keuangan Islam, secara umum, tantangan yang dihadapi adalah bagaimana IMW dapat berkembang lebih luas lagi.

Tantangan utama untuk pertumbuhan masa depan dari industri ini adalah kurangnya SDM atau sumber daya manusia yang berkualitas. Beberapa ahli ekonomi Islam dengan kapasitas yang memadai membuat peraturan produk-produk baru, seperti beberapa pengacara yang terlatih, bankir, dan staf teknis yang diperlukan untuk melaksanakan 
kontrak dan mengembangkan produk baru. Beberapa ahli ekonomi Islam tersebut harus melalui masa training (pelatihan)selama sekitar 15 tahun dalam bidang hukum Islam dan keuangan. Para pemain di industri ini sering kekurangan informasi yang diperlukan, dan data-data yang diperlukan seringkali tidak lengkap dan tidak konsisten.

Selain sumber daya manusia yang terampil dan berpendidikan, agar IWM maju, dibutuhkan standarisasi yang lebih tinggi dalam produk-produk investasi dan konsistensi dalam penerapan kriteria screening untuk kepatuhan syariah. Seringkali, tidak ada interpretasi yang sama dari hukum Islam yang berlaku di seluruh wilayah, sehingga setiap lembaga keuangan di suatu wilayah memiliki dewan syariah masingmasing untuk menentukan produk yang halal (diijinkan) dalam Islam.

Investor Islam yang berpenghasilan tinggi pada masa sekarang ini terbukti lebih piawai dan berpengalaman dalam tuntutan keuangan mereka daripada di masa lalu, mereka dituntut untuk melindungi dana mereka dan produk pasar modal kompleks lainnya untuk mendapatkan pengembalian yang kompetitif. Meskipun keyakinan terhadap agama mengenai produk keuangan sangat penting bagi investor, potensi terhadap pengembaliannya juga menjadi pertimbangan bagi investor. Secara umum diketahui bahwa baik investor swasta maupun kelembagaan lebih memilih untuk berinvestasi dalam dana syariah, asalkan mereka memperoleh pengembalian yang kompetitif.

\section{Prospek terhadap Pengelolaan Kekayaan Pribadi secara Islami di Indonesia}

Munculnya outlet-outlet berikut produk yang semakin bervariasi jasa pelayanan keuangan syariah ternyata secara perlahan memunculkan bentuk industri keuangan syariah baru, yaitu pengelolaan kekayaan pribadi secara syariah (Islamic Wealth Management), atau dalam beberapa aspek pembahasan pengelolaan kekayaan ini dikenal pula sebagai perencanaan keuangan keluarga secara syariah (Islamic Financial Planning). Beragam portofolio keuangan syariah berupa deposito, reksadana, asuransi, pasar modal dan lain sebagainya menjadi pilihan keluarga Muslim kelas menengah ke atas dalam pengelolaan harta mereka. Perkembangan industri tersebut mampu melayani 
golongan masyarakat tersebut terhadap kebutuhan aktivitas ekonomi sesuai dengan prinsip-prinsip syariah. Kebutuhan tersebut muncul seiring dengan semakin berkembangnya populasi Muslim menengah ke atas Indonesia yang merefleksikan pula semangat keislaman yang tumbuh di antara mereka (Pengelolaan Kekayaan Peribadi. $\begin{array}{llllll}\text { Diakses dari situs pada tanggal } 22 & \text { Desember } 2015 .\end{array}$ http://www.syariahmandiri.co.id/category/edukasi-syariah/islamic-knowledge/).

Penghasilan cukup memadai dan tingkat saving yang semakin meningkat di kalangan keluarga-keluarga Muslim, semakin merangsang industri jasa pengelolaan kekayaan, terlebih lagi kondisi tersebut didukung kondisi dimana pribadi-pribadi Muslim tersebut semakin sempit memiliki waktu luang untuk mengurusi kekayaan mereka. Kehadiran pengelola kekayaan tentu saja akan sangat membantu kebutuhan segmentasi masyarakat ini. Bahkan pengelolaan kekayaan ini bukan hanya bersifat pada pengelolaan yang berorientasi profit tetapi juga orientasi sosial dan kebutuhan keluarga lainnya, seperti alokasi kekayaan untuk membayar kewajiban zakat, infak, sedekah atau wakaf. Selain itu untuk pengeluaran kebutuhan keluarga contohnya seperti alternatif dan alokasi biaya sekolah Islami untuk anak dan rekreasi.

Islamic Wealth Management saat ini di Indonesia memiliki potensi yang cukup besar untuk dapat dikembangkan menjadi produk perbankan syariah. Pengelolaan kekayaan pribadi ini memungkinkan nasabah bank syariah untuk dapat melakukan investasi yang sesuai dengan prinsip syariah. Selain itu, dengan adanya pengelolaan kekayaan pribadi ini juga memudahkan bagi para pihak yang berkepentingan terhadap penyaluran dan penerimaan zakat. Dengan demikian, prospek pengelolaan kekayaan pribadi di Indonesia ini memiliki peranan yang cukup penting terhadap kesejahteraan masyarakat.

\section{Simpulan}

Pengelolaan kekayaan Islami yang dikenal juga sebagai perencanaan keuangan keluarga secara syariah (Islamic Financial Planning)merupakan industri keuangan yang berfungsi untuk mengelola kekayaan masyarakat muslim untuk dapat diinvestasikan maupun dikelola dengan cara-cara yang sesuai dengan syariah. Industri keuangan pengelolaan kekayaan pribadi semakin berkembang juga di Indonesia dikarenakan 
semakin meningkatnya jumlah kekayaan yang dimiliki oleh penduduk muslim dan juga kesadaran mereka untuk melakukan investasi dan pengelolaan kekayaan secara prinsipprinsip Islami. Pengelolaan kekayaan Islami termasuk di dalamnya adalah memperoleh kekayaan, peningkatan kekayaan, perlindungan terhadap kekayaan, dan pemurnian kekayaan. Islam mengajarkan bahwa kekayaan yang telah diperoleh tidak hanya milik pribadi, namun juga terdapat hak dari orang lain.

Hak ini dapat dipenuhi dengan membayar zakat. Zakat di Indonesia terus mengalami perkembangan. Baznas mentargetkan pencapaian jumlah pengumpulan ZIS (zakat, infaq dan sedekah) nasional sebesar Rp 5 triliun untuk tahun 2016 dan Rp 10 triliun pada tahun 2020. Pengelolaan kekayaan pribadi sebagai salah satu produk di industri keuangan Islam Indonesia, saat ini masih layak untuk terus dikembangkan. Berkembangnya industri pengelolaan kekayaan pribadi di Indonesia diharapkan dapat mengurangi tingkat kemiskinan dan meningkatkan kesejahteraan masyarakat.

\section{DAFTAR PUSTAKA}

Al-Jaziri, Abdurrahman, 1990. Kitab 'ala Mazahib al-Arba'ah, jilid 1, Beirut: Dar alFikri.

Aravik, Havis. 2016. Ekonomi Islam; Konsep, Teori dan Aplikasi, Serta Pandangan Pemikiran Ekonomi Islam dari Abu Ubaid Sampai al-Maududi, Malang: Empat Dua.

Ghazary, Abdul Rahman, Ghufron Hasan, dan Sapiuddin Shiddiq. 2012. Fiqh Muamalah. Jakarta: Kencana Prenada Media Group. 
44 | Choirunnisak Konsep Pengelolaan Kekayaan dalam Islam

Mardani. 2012. Fiqh Ekonomi Syariah. Fiqh Muamalah. Jakarta: Kencana Prenada Media Group.

Shanmugam, Bala dan Zaha Rina Zahari. 2009. A Primer on Islamic Finance. CFA Institute.

Soemitra, Andri, 2009. Bank dan Lembaga Keuangan Syariah, Edisi Pertama, Jakarta: Kencana.

Suhendi, Hendi, 2013. Fiqh Muamalah. Membahas Ekonomi Islam. Jakarta: PT. RajaGrafindo Persada.

Vogel, Frank E. \& Samuel. L. Hayes, 2009. Hukum Keuangan Islam. Konsep, Teori dan Praktik., Bandung; Nusa Media.

\section{SITUS WEB:}

http://www.republika.co.id/berita/koran/khazanah-koran/15/12/12/nz8qgg1-capaianzakat-nasional-hanya-satu-persen, akses tanggal 19 Desember 2015, pukul 10.13 WIB.

http://poskotanews.com/2015/12/03/baznas-targetkan-angka-kemiskinan-turun-1persen-setahun/, akses tanggal 18 Desember 2015, pukul 20.29 WIB.

http://forumzakat.org/baznas-targetkan-pengumpulan-zis-mencapai-rp-5-triliun/, akses tanggal 18 Desember 2015, pukul 20.32 WIB.

http://forumzakat.org/kementerian-agama-dorong-masyarakat-salurkan-zakat-melaluilembaga/, akses tanggal 18 Desember 2015, pukul 20.36 WIB.

Pengelolaan Kekayaan Peribadi. Diakses dari situs pada tanggal 22 Desember 2015. http://www.syariahmandiri.co.id/category/edukasi-syariah/islamic-knowledge/. 